\title{
Supergroup F Wolbachia bacteria parasitise lice (Insecta: Phthiraptera)
}

\author{
Catherine Covacin • Stephen C. Barker
}

Published online: 10 January 2007

(C) Springer-Verlag 2007

\section{Parasitol Res (2007) 100:479-485}

Some of the genbank numbers listed in Table 1 are incorrect. The correct accession numbers are given here:

Wolbachia sp. of Columbicola columbae DQ498981

Wolbachia sp. of Menacanthus stramineus DQ498982

Wolbachia sp. of Hohorstiella lata DQ498983

Wolbachia sp. of Campanulotes bidentatus compar DQ498984

Wolbachia sp. of Bovicola ovis DQ498985

Wolbachia sp. of Pediculus capitis (Bris) DQ498986

Wolbachia sp. of Pediculus capitis (Tas 1) DQ498987

Wolbachia sp. of Peduculus capitis (Tas 2) DQ498988

The online version of the original article can be found at http://dx.doi. org/10.1007/s00436-006-0309-6 of the article with published errors.

C. Covacin $(\square) \cdot$ S. C. Barker

Parasitology Section, School of Molecular and Microbial

Sciences, The University of Queensland,

Brisbane 4072, Australia

e-mail: c.covacin@uq.edu.au 